J. Lake Sci. (湖泊科学), 2014, 26(5):759-766

http: //www. jlakes.org. E-mail : jlakes@niglas.ac.cn

(C) 2014 by Journal of Lake Sciences

\title{
2012 年夏季三江平原湿地抚远地区浮游植物群落结构及多样性
}

\author{
国超旋, 刘 妍, 范亚文**, 李 慧 \\ (哈尔滨师范大学植物学省级重点实验室, 哈尔滨 150025)
}

\begin{abstract}
摘 要: 2012 年 6 月 (夏季) 对三江平原湿地抚远地区水域的浮游植物进行调查, 设置了 10 个采样点, 经鉴定共有浮游植 物 262 个分类单元,包括 239 种 19 变种 4 变型, 隶属于 7 门 9 纲 22 目 32 科 73 属. 通过对浮游植物群落结构的初步分析, 得出三江平原湿地抚远地区水域浮游植物群落结构组成以绿藻门、硅藻门、裸藻门为主, 种类数为绿藻门 $(42.6 \%)>$ 硅藻 门 $(22.8 \%)>$ > 裸藻门 $(20.9 \%)$, 细胞密度在 $3.88 \times 10^{4} \sim 278.07 \times 10^{4} \mathrm{cells} / \mathrm{L}$ 之间. 聚类分析结果显示, 可以将 10 个采样 点分为两组, 即农场区 5 个样点为一组, 非农场区 5 个样点为另一组, 两大区域的浮游植物群落结构差异明显, 水体类型 及生态环境的不同是其存在差异的主要原因. 浮游植物多样性指数相对较为一致, Shannon-Wiener 多样性指数均在 2 左 右, Margalef 丰富度指数均大于 3 ,Pielou 均匀度指数在 $0.3 \sim 0.5$ 之间. 综合群落结构以及多样性分析表明,三江平原湿地 抚远地区水域浮游植物物种丰富度较高,多样性良好.
\end{abstract}

关键词: 三江平原湿地扰远地区;浮游植物;群落结构;多样性

\section{Characteristics and diversity of phytoplankton community structures in the Sanjiang Plain Wetland (Fuyuan region) in the summer, 2012}

\author{
GUO Chaoxuan, LIU Yan, FAN Yawen \& LI Hui \\ ( Heilongjiang Provincial Key Laboratory of Botany, Harbin Normal University, Harbin 150025, P. R. China)
}

\begin{abstract}
Phytoplankton samples of the Sanjiang Plain Wetland (Fuyuan region) were collected from 10 sampling sites in June 2012. A total of 262 taxa belonging to 7 phyla, 9 classes, 22 orders, 32 families, 73 genera, 239 species, 19 varieties and 4 forms were identified. Chlorophyta, Bacillariophyta and Euglenophyta dominated the phytoplankton community, were 42.6\% , $22.8 \%$ and $20.9 \%$, respectively. The total cell density at different sampling sites varied from $3.88 \times 10^{4}-278.07 \times 10^{4}$ cells $/ \mathrm{L}$. The results of cluster analysis divided the 10 sampling sites into two regions: farm region and non-farm region, and the differences in phytoplankton communities of these two regions were significant. The Shannon-Wiener diversity indices were about 2, Margelef indices were above 3 , and Pielou evenness indices ranged from 0.3-0.5. Phytoplankton compositions in the farm region were more complex than those in non-farm region. Based on the species composition and diversities, it was suggested that the phytoplankton diversity of the Sanjiang Plain Wetland (Fuyuan region) was good and appropriate for the growth of the phytoplankton.

Keywords: Sanjiang Plain Wetland (Fuyuan region); phytoplankton; community structure; diversity
\end{abstract}

湿地是地球上最重要的生态环境之一,是介于陆生生态系统与水生生态系统之间的过渡区域,具有独 特的水文特点, 扮演着重要的生态角色 ${ }^{[1]}$. 浮游植物作为湿地水域环境中的初级生产者和食物链的基础环 节, 在物质循环和能量转化过程中起着重要作用, 其群落结构及多样性是反映水环境状况的重要指标 ${ }^{[2]}$. 目 前,国内外通过对某个典型的湖泊、河流、湿地或区域的浮游植物群落结构变化和各种多样性指数对水体生 态环境监测做了大量的研究, Reynolds 等 ${ }^{[3-6]}$ 的研究表明浮游植物的物种组成、生物量受季节变化,氮磷等营 养物质、光照和温度的影响,水生生态的变化与浮游植物的群落特征密切相关,前者的变动往往导致后者群

* 国家自然科学基金项目(31070183,31270250)、黑龙江省教育厅重点项目(12521z011)、黑龙江省高校科技创新团队研究计 划项目和哈尔滨师范大学科技创新团队研究计划项目 (KJTD-2011-2) 联合资助. 2013-10-12 收稿;2013-12-31 收修改稿. 国超旋(1987 ), 女, 硕士研究生;E-mail : gchaoxuan@163.com.

** 通信作者;E-mail:fanyaw@163.com. 
落组成与结构的变化. 生物的多样性指数亦随水体指标的变化而变动 ${ }^{[7]}$.

三江平原湿地 $\left(45^{\circ} 29^{\prime} \sim 48^{\circ} 30^{\prime} \mathrm{N}, 130^{\circ} 20^{\prime} \sim 135^{\circ} 05^{\prime} \mathrm{E}\right)$ 位于黑龙江省东北部, 土地总面积约 $108800 \mathrm{~m}^{2}$, 是由黑龙江、松花江及乌苏里江冲积而成的低平原, 同时也是我国面积最大的淡水湿地. 三江平原湿地抗远 地区 $\left(47^{\circ} 35^{\prime} \sim 48^{\circ} 11^{\prime} \mathrm{N}, 133^{\circ} 51^{\prime} \sim 134^{\circ} 06^{\prime} \mathrm{E}\right)$ 地处三江平原湿地的东北边缘, 东北两面与俄罗斯、黑龙江、乌 苏里江相望, 南邻饶河, 西接同江. 主要地貌特征为冲积平原、沼泽洼地; 主要土壤类型为草甸土与沼泽土, 有机质含量丰富. 自然水域面积 $273 \mathrm{~m}^{2}$, 有大小河流 50 多条, 星罗棋布的自然湖沼 700 多个, 沼泽湿地遍布 其中. 本文首次对三江平原湿地抚远地区浮游植物群落结构及其多样性进行初步研究, 探讨浮游植物与该 区域环境因子之间的相互关系, 为今后三江平原湿地浮游植物研究提供基础资料, 也为该地区自然资源的 合理开发、利用以及环境保护规划提供一些科学依据.

\section{1 材料与方法}

\section{1 采样点设置}

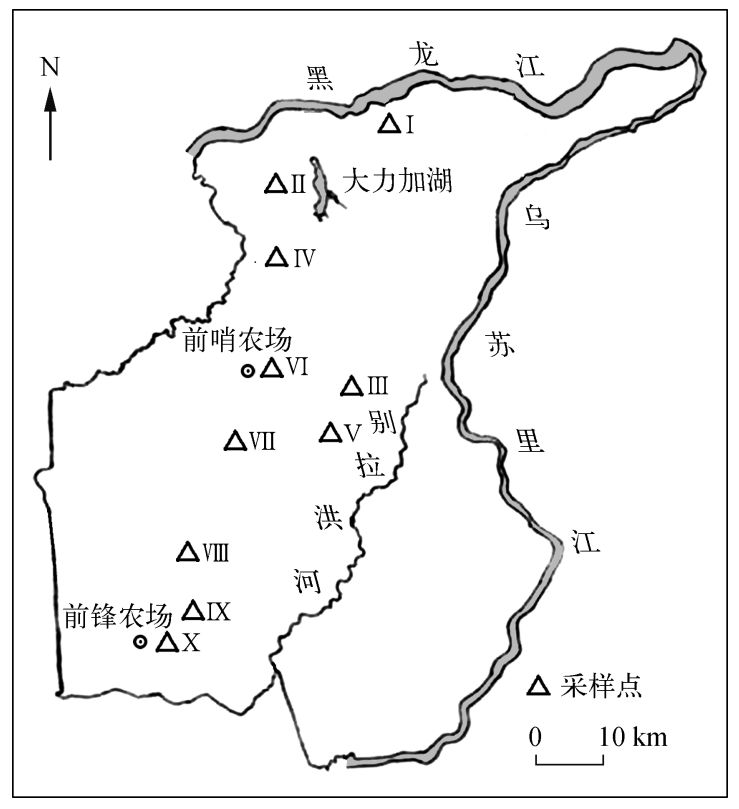

图 1 三江平原湿地抚远地区采样点分布

Fig. 1 Distribution of sampling sites in the Fuyuan region of Sanjiang Plain Wetland
2012 年夏季在三江平原湿地抚远地 区共设置 10 个采样点 (图 1 ), 本研究在 自然区域划分及生态特点的基础上, 分 为农场区与非农场区两大区域. 沿着前 哨农场一路到前锋农场, 共设置 5 个采 样点 ( VI、VII、VIII、IX、X), 采集水域均 为农田区附近, 窄于 $4 \mathrm{~m}$ 的小溪流, 且样 点VIII、X 水体有异味, VI、VII均为一侧有 农田、一侧临近公路, 水质含沙, 水体微 黄. 非农场区主要包括大型水体及湿地 区, 如: 黑龙江畔 I (开放水面, 人类活动 频繁)、大力加湖 II (湖面宽阔, 船舶停 靠, 沿岸有芦苇分布)、别拉洪河 III (水流 慢, 水体黄) 、三江湿地 IV (以塔头沼泽为 主的流动水湿地) 及别拉洪河流域湿地 $\mathrm{V}$ (缓流水湿地).

\section{2 样品的采集、计数与指标测定}

浮游植物定性样品采集使用 $25^{\#}$ 浮 游生物网, 在水面下 $0.5 \mathrm{~m}$ 处作 “ $\infty$ ” 字 形捞取, 采集的样品加人 $4 \%$ 甲醛固定保 存. 定量样品的采集是利用采水器在水

下 $0.5 \sim 1.0 \mathrm{~m}$ 处取 $1 \mathrm{~L}$ 水样, 用 $15 \mathrm{ml}$ 鲁哥试剂固定后沉淀 $48 \mathrm{~h}$ 并浓缩至 $30 \mathrm{ml}$. 取 $0.1 \mathrm{ml}$ 浓缩水样于浮游 生物计数框中, 在 $10 \times 40$ 倍光学显微镜下进行鉴定并计数. 硅藻鉴定主要参考文献 [8-9], 其他藻类鉴定主 要参考文献 [10-12]. 使用高精度笔式便携 $\mathrm{pH}$ 计KL-009 III 现场测定水温和 $\mathrm{pH}$, 便携式电导率仪 DDB-11 A 测 定电导率, TDS 水质检测笔测定总溶解固体含量 (TDS).

\section{3 数据分析}

运用 Excel 2003 处理数据及作图, 聚类分析和非度量多维标度分析 (MDS) 主要采用大型多元分析 软件 PRIMER 5.0, 样点聚类是基于物种相似性矩阵的基础上使用其子模块 Cluster 分析. 多样性指数 包括 Margalef 丰富度指数 $(H)$ 、Shannon-Wiener 多样性指数 $\left(H^{\prime}\right) 、$ Pielou 均匀度指数 $(J)$, 各指数计算 公式分别为:

$$
H=(S-1) / \ln N, H^{\prime}=-\sum_{i=1}^{S} P_{i} \ln P_{i}, J=H^{\prime} / \ln S
$$


式中, $S$ 为浮游植物种数, $N$ 为浮游植物个体总数, $P_{i}$ 为第 $i$ 种的个体数 $\left(N_{i}\right)$ 占个体总数的比例. 当 $H=0 \sim$ 1 , 为重污染; $H=1 \sim 3$, 为中污染; $H>3$, 为轻污染或无污染. $H^{\prime}=0 \sim 1$, 为重污染; $H^{\prime}=1 \sim 3$, 为中污 染, 其中 $1 \sim 2$ 为 $\alpha$-中污, $2 \sim 3$ 为 $\beta$-中污; $H^{\prime}>3$, 为清洁. $J=0 \sim 0.3$, 为重污染; $J=0.3 \sim 0.5$, 为中污染; $J=0.5 \sim 0.8$, 为轻或无污染.

优势度 $(y)$ 的计算公式为:

$$
y=f_{i} \cdot P_{i}
$$

式中, $f_{i}$ 为第 $i$ 种浮游植物在采样点中的出现频率, $y \geqslant 0.02$ 定为优势种 ${ }^{[13]}$.

出现率 $(\%)=$ 出现的样点数/样点总数 $\times$ $100 \%$,相对密度 $(\%)=$ 物种的密度/浮游植物总 密度 $\times 100 \%{ }^{[14]}$.

表 1 各采样点水体环境因子

Tab. 1 Environmental factors of water from each sampling site

\begin{tabular}{cccccc}
\hline & 采样点 & $\mathrm{pH}$ & $\begin{array}{c}\text { 水温/ } \\
{ }^{\circ} \mathrm{C}\end{array}$ & $\begin{array}{c}\text { 电导率/ } \\
(\mu \mathrm{S} / \mathrm{cm})\end{array}$ & $\begin{array}{c}\mathrm{TDS} / \\
(\mathrm{mg} / \mathrm{L})\end{array}$ \\
\hline 非农场区 & $\mathrm{I}$ & 8.63 & 17.6 & 94 & 60 \\
& II & 7.62 & 20.4 & 88 & 55 \\
& III & 7.39 & 18.0 & 123 & 77 \\
& IV & 7.06 & 21.0 & 108 & 68 \\
农场区 & V & 7.35 & 17.0 & 110 & 76 \\
& VI & 7.60 & 15.0 & 119 & 74 \\
& VII & 7.05 & 16.0 & 115 & 72 \\
& VIII & 7.07 & 17.0 & 87 & 51 \\
& IX & 7.10 & 16.0 & 89 & 58 \\
& X & 7.41 & 19.0 & 147 & 93 \\
\hline
\end{tabular}
为 $147 \mu \mathrm{S} / \mathrm{cm} 、 93 \mathrm{mg} / \mathrm{L}$ (表 1 ). 2.1 .2 三江平原湿地抚远地区浮游植物种类组成 2012 年 6 月在三江平原湿地抚远地区共采集并鉴
定浮游植物 262 个分类单元,包括 239 种 19 变种 4 变型, 隶属于 7 门 9 纲 22 目 32 科 73 属. 其中绿藻 门 34 属 112 种, 占藻类总数的 $42.7 \%$; 硅藻门 18 属 60 种, 占 $22.9 \%$; 裸藻门 6 属 55 种, 占 $21.0 \%$; 蓝藻门 7 属 21 种, 占 $8.0 \%$; 甲藻门 1 属 6 种, 占 $2.3 \%$; 黄藻门 2 属 5 种, 占 $1.9 \%$; 隐藻门 1 属 3 种, 占 $1.1 \%$.

浮游植物各门类的种类数和密度分布见表 2 . 就种类数而言, 农场区溪流生境中共鉴定浮游植物 36 属 129 种, 其中, 硅藻 43 种 (占 $33.33 \%$ ); 裸藻 33 种 (占 $25.58 \%$ ); 隐藻种类不多但为密度上的优势类 群,平均密度为 $57.94 \times 10^{4} \mathrm{cell} / \mathrm{s} / \mathrm{L}$, 相对密度为 $68.29 \%$. 非农场区水域共鉴定浮游植物 47 属 174 种, 河 流生境中共发现 33 属 71 种, 其中, 绿藻门 46 种 (占 $65 \%$ ), 硅澡门 19 种 (占 $27 \%$ ); 硅藻的相对密度最 大, 为 $69.63 \%$, 其次是绿藻为 $29.98 \%$. 湖泊生境中鉴定出浮游植物 28 属 53 种, 其中绿藻门 29 种 (占 $55 \%$ ), 硅藻门 13 种 (占 $25 \%$ ); 硅藻的相对密度最大, 为 $74.17 \%$, 其次是绿藻为 $21.43 \%$. 湿地生境 中共鉴定浮游植物 39 属 77 种, 绿藻门 30 种 (占 39\%), 硅藻门 22 种 (占 29\%) ; 硅藻的相对密度最大, 为 $56.29 \%$, 绿藻次之, 为 $20.11 \%$ (表 2).

2.1 .3 三江平原湿地抚远地区浮游植物优势种 三江平原湿地扰远地区浮游植物优势种、出现率和密度 见表 3 , 以大于 $2 \%$ 作为优势种 ${ }^{[13]}$, 共 21 种. 其中, 农场区优势种 10 种, 就出现率和相对密度而言, 隐澡门中 的啮蚀隐藻和卵形隐藻为绝对优势种, 两者共占总密度的 $82.35 \%$. 非农场区优势种 11 种, 河流生境的优势 种均属于绿藻、硅藻门, 谷皮菱形藻占绝对优势, 出现率为 $100 \%$, 相对密度为 $13.09 \%$; 湖泊生境中, 优势种 也同属于绿藻门、硅藻门, 颗粒直链藻极狭变种和梅尼小环藻占绝对优势, 出现率均为 $100 \%$, 相对密度分别 为 $73 \%$ 和 $17 \%$; 湿地生境中, 优势种主要为绿藻和硅藻, 蓝藻门的断裂颤藻与颗粒颤藻也占有一定的优势, 但相对密度不高, 分别为 $10 \%$ 和 $12 \%$ （表 3 ). 
表 2 农场区与非农场区水域浮游植物种数及密度

Tab. 2 Number of phytoplankton species and density in farm and non-farm areas

\begin{tabular}{|c|c|c|c|c|c|c|c|}
\hline 区域 & 生境 & 门类 & 种数 & $\begin{array}{c}\text { 种数比例/ } \\
\%\end{array}$ & $\begin{array}{c}\text { 密度范围/ } \\
\left(\times 10^{4} \text { cells/L }\right)\end{array}$ & $\begin{array}{c}\text { 平均密度/ } \\
\left(\times 10^{4} \text { cells/L }\right)\end{array}$ & $\begin{array}{c}\text { 相对密度/ } \\
\%\end{array}$ \\
\hline \multirow[t]{7}{*}{ 农场区 } & \multirow{7}{*}{$\begin{array}{c}\text { 溪流 } \\
\text { (共 } 129 \text { 种) }\end{array}$} & 硅藻 & 43 & 33.33 & $0.13 \sim 49.7$ & 13.30 & 15.68 \\
\hline & & 绿藻 & 28 & 21.70 & $0 \sim 10.13$ & 1.19 & 1.40 \\
\hline & & 裸藻 & 33 & 25.58 & $0.29 \sim 22.6$ & 8.37 & 9.87 \\
\hline & & 蓝藻 & 12 & 9.30 & $0 \sim 4.63$ & 1.19 & 1.40 \\
\hline & & 甲藻 & 5 & 3.88 & $0 \sim 6.71$ & 1.54 & 1.82 \\
\hline & & 隐藻 & 3 & 2.32 & $1.88 \sim 203.00$ & 57.94 & 68.29 \\
\hline & & 黄藻 & 5 & 3.88 & $0 \sim 1.00$ & 0.20 & 0.24 \\
\hline \multirow[t]{14}{*}{ 非农场区 } & \multirow{4}{*}{$\begin{array}{c}\text { 河流 } \\
\text { (共 } 71 \text { 种） }\end{array}$} & 硅藻 & 19 & 0.27 & $3.06 \sim 193.00$ & 98.03 & 69.63 \\
\hline & & 绿藻 & 46 & 0.65 & $0 \sim 84.43$ & 42.21 & 29.98 \\
\hline & & 裸藻 & 2 & 0.03 & $0 \sim 0.64$ & 0.32 & 0.23 \\
\hline & & 蓝藻 & 4 & 0.06 & $0 \sim 0.44$ & 0.22 & 0.16 \\
\hline & \multirow{5}{*}{$\begin{array}{c}\text { 湖泊 } \\
\text { (共 } 53 \text { 种) }\end{array}$} & 硅藻 & 13 & 0.25 & 93.04 & 93.04 & 74.17 \\
\hline & & 绿藻 & 29 & 0.55 & 26.88 & 26.88 & 21.43 \\
\hline & & 裸藻 & 2 & 0.04 & 0.09 & 0.09 & 0.07 \\
\hline & & 蓝藻 & 8 & 0.15 & 4.20 & 4.20 & 3.35 \\
\hline & & 甲藻 & 1 & 0.02 & 1.25 & 1.25 & 1.00 \\
\hline & \multirow{5}{*}{$\begin{array}{c}\text { 湿地 } \\
\text { (共 } 77 \text { 种) }\end{array}$} & 硅藻 & 22 & 0.29 & $3.88 \sim 6.15$ & 5.01 & 56.29 \\
\hline & & 绿藻 & 30 & 0.39 & $0.13 \sim 3.45$ & 1.79 & 20.11 \\
\hline & & 裸藻 & 14 & 0.18 & $0 \sim 2.25$ & 1.13 & 12.70 \\
\hline & & 蓝藻 & 10 & 0.13 & $0 \sim 0.15$ & 0.08 & 0.90 \\
\hline & & 隐藻 & 1 & 0.01 & $0.55 \sim 1.25$ & 0.90 & 10.11 \\
\hline
\end{tabular}

2.1 .4 三江平原湿地抚远地区浮游植物细胞密度 总体上, 三江平原湿地抚远地区浮游植物细胞密度变 化范围在 $3.5 \times 10^{4} \sim 278.1 \times 10^{4}$ cells $/ \mathrm{L}$ 之间, 平均密度为 $84.0 \times 10^{4}$ cells $/ \mathrm{L}($ 图 2 ). 非农场区包括样点 $\mathrm{I}$ 、 II 、III、IV、V , 总细胞密度为 $425.8 \times 10^{4}$ cells $/$ L. 其中属于河流生境的样点 I 、 III 的总细胞密度为 $281.6 \times$ $10^{4}$ cells $/ \mathrm{L}$; 湖泊生境样点 II 的细胞密度为 $125.5 \times 10^{4}$ cells $/ \mathrm{L}$; 湿地生境样点 $\mathrm{IV} 、 \mathrm{~V}$ 的总细胞密度为 $8.9 \times$ $10^{4}$ cells $/ \mathrm{L}$; 农场区溪流生境包括样点 VI、VII、VII 、IX、X, 总细胞密度为 $424.2 \times 10^{4}$ cells $/ \mathrm{L}$.

\section{2 三江平原湿地抚远地区浮游植物多样性指数}

三江平原湿地抚远地区各水体中浮游植物的 Margalef 丰富度指数大小依次为: 湖泊生境 (7.17) > 河流 生境 $(5.59)>$ 湿地生境 (4.96)> 溪流生境 (4.40); Shannon-Wiener 多样性指数大小依次为: 河流生境 (2.66) > 湿地生境 $(2.52)>$ 湖泊生境 $(2.08)>$ 溪流生境 $(1.87)$; Pielou 均匀度指数大小依次为: 湿地生境 $(0.80)>$ 河流生境 $(0.71)>$ 溪流生境 $(0.59)>$ 湖泊生境 $(0.52)$. 虽然不同多样性指数在 4 个生境中的排 列顺序不尽相同, 但各指数都处于物种多样性遭破坏的临界值以内, 表明三江平原湿地抚远各地区目前水 体浮游植物的多样性变化属正常范围.

\section{3 浮游植物群落分布聚类分析和多维标度分析}

利用 PRIMER 5.0 软件对三江平原湿地抚远地区 10 个采样点浮游植物群落进行聚类分析和 MDS 分析 (图 3 ), 结果表明, 各样点浮游植物群落按结构特征分成 2 组: 第一组包括样点 I 、II、III、IV、V, 均分布 于非农场区; 第二组包括样点 VI、VII、VII 、IX 、X, 均分布于农场区. 这表明三江平原湿地抚远地区农场区与 非农场区水域浮游植物群落结构存在较大差异.

\section{3 讨论}

\section{1 三江平原湿地抚远地区夏季浮游植物群落结构特征}

浮游植物种类组成是浮游植物对水体环境适应的结果 ${ }^{[15-16]}$. 抚远地区水域浮游植物以绿藻门、硅藻门、 裸藻门在种类上占绝对优势. 其中广布种为 37 个分类单位, 绿藻门占大多数, 如: 具角鼓藻 (Cosmarium an- 
gulosum)、钝鼓藻 $(C$. obtusatum) 、美丽网球藻 (Dictyosphaerium pulchellum)、短刺盘星藻 (Pediastrum boryanum) 等. 抚远地区为温带湿润、半湿润大陆性季风气候, 夏季的水域温度仍然较低 (平均为 $17.7^{\circ} \mathrm{C}$ ), 又因降 雨及水流的冲刷等原因造成各样点的浮游植物细胞密度相对较低, 平均密度仅为 $84.0 \times 10^{4}$ cells/L.

表 3 农场区与非农场区浮游植物优势种出现率及密度

Tab. 3 Occurrence frequency and density of the dominant phytoplankton species in farm and non-farm areas

\begin{tabular}{|c|c|c|c|c|c|c|}
\hline 区域 & 生境 & 种类 & $\begin{array}{c}\text { 出现率/ } \\
\%\end{array}$ & $\begin{array}{c}\text { 密度范围/ } \\
\left(\times 10^{4} \text { cells } / \mathrm{L}\right)\end{array}$ & $\begin{array}{c}\text { 平均密度/ } \\
\left(\times 10^{4} \text { cells } / \mathrm{L}\right)\end{array}$ & $\begin{array}{c}\text { 相对密度/ } \\
\%\end{array}$ \\
\hline \multirow[t]{10}{*}{ 农场区 } & \multirow{10}{*}{ 溪流 } & 啮蚀隐藻 Cryptomonas erosa & 80 & $0 \sim 122.50$ & 33.57 & 49.86 \\
\hline & & 卵形隐藻 Cryptomonas ovata & 60 & $0 \sim 73.94$ & 21.87 & 32.49 \\
\hline & & 罐形陀螺藻 Strombomonas urceolata & 20 & $0 \sim 5.69$ & 1.14 & 1.69 \\
\hline & & 河生陀螺藻 Strombomonas fluviatilis & 20 & $0 \sim 5.83$ & 1.17 & 1.73 \\
\hline & & 圆形囊裸藻 Trachelomona srotunda & 20 & $0 \sim 2.33$ & 0.47 & 0.69 \\
\hline & & 尖尾蓝隐藻 Chroomonas acuta & 20 & $0 \sim 7.44$ & 1.49 & 2.21 \\
\hline & & 谷皮菱形藻 Nitzschia palea & 20 & $0 \sim 23.13$ & 4.63 & 6.87 \\
\hline & & 小型异极藻 Gomphonema parvulum & 20 & $0 \sim 9.75$ & 1.95 & 2.89 \\
\hline & & 扁圆卵形藻 Cocconeis placentula & 20 & $0 \sim 6.25$ & 0.13 & 0.19 \\
\hline & & 固氮鱼腥藻 Anabaena azotica & 20 & $0 \sim 4.63$ & 0.93 & 1.38 \\
\hline \multirow[t]{16}{*}{ 非农场区 } & \multirow[t]{6}{*}{ 河流 } & 梅尼小环藻 Cyclotella meneghiniana & 50 & $0 \sim 139.64$ & 69.82 & 71.45 \\
\hline & & 谷皮菱形藻 ～～～～～～～～ & 100 & $0.58 \sim 25.00$ & 12.79 & 13.09 \\
\hline & & 二形栅藻 Scenedesmus dimorphus & 50 & $0 \sim 11.93$ & 5.97 & 6.10 \\
\hline & & 顶雉十字藻 Crucigenia apiculata & 50 & $0 \sim 7.14$ & 3.57 & 3.65 \\
\hline & & 线毛平板藻 Tabellaria flocculosa & 50 & $0 \sim 10.14$ & 5.07 & 5.19 \\
\hline & & 窄双菱藻 Surirella angusta & 50 & $0 \sim 1.02$ & 0.51 & 0.52 \\
\hline & \multirow[t]{4}{*}{ 湖泊 } & $\begin{array}{l}\text { 颗粒直链藻极狭变种 Melosira granulate } \\
\text { var. angustissima }\end{array}$ & 100 & 66.61 & 33.31 & 73.00 \\
\hline & & 梅尼小环藻 & 100 & 15.71 & 7.86 & 17.00 \\
\hline & & 被甲栅藻 Scenedesmus armatus & 100 & 6.25 & 3.13 & 7.00 \\
\hline & & $\begin{array}{l}\text { 镰形纤维藻奇异变种 Ankistrodesmus } \\
\text { falcatus var. mirabilis }\end{array}$ & 100 & 3.13 & 1.57 & 3.00 \\
\hline & \multirow[t]{6}{*}{ 湿地 } & 谷皮菱形藻 & 100 & $2.35 \sim 1.50$ & 1.93 & 40.00 \\
\hline & & 变异直链藻 Melosira varians & 50 & $0 \sim 0.55$ & 0.28 & 6.00 \\
\hline & & 线毛平板藻 & 50 & $0 \sim 1.50$ & 0.75 & 15.00 \\
\hline & & 断裂颤藻 Oscillatoria fraca & 50 & $0 \sim 1.00$ & 0.50 & 10.00 \\
\hline & & 颗粒颤藻 Oscillatoria granulata & 50 & $0 \sim 1.13$ & 0.57 & 12.00 \\
\hline & & 镰形纤维藻奇异变种 & 50 & $0 \sim 1.70$ & 0.85 & 17.00 \\
\hline
\end{tabular}

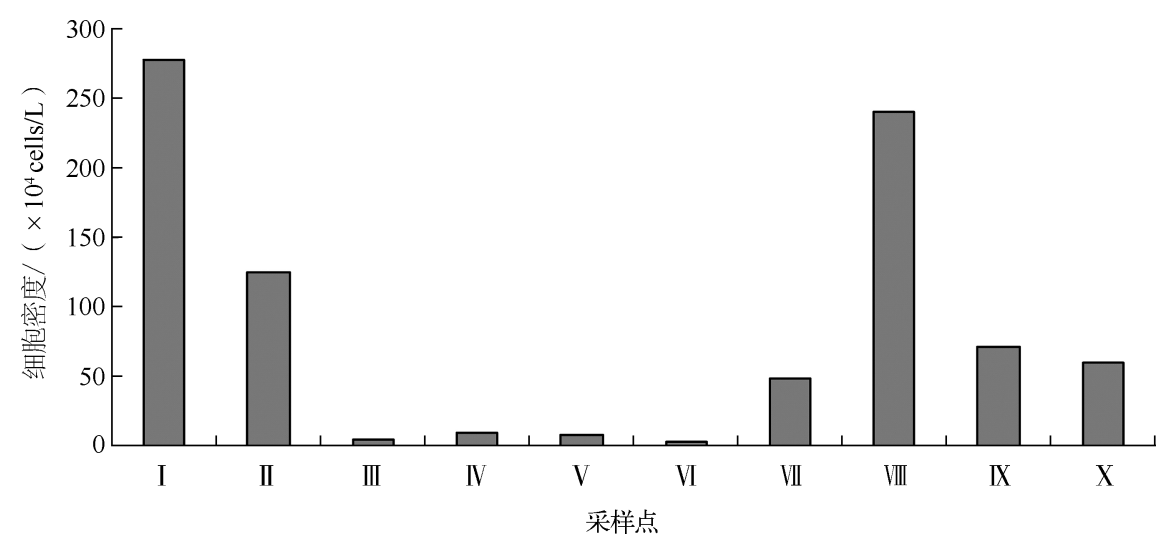

图 2 各采样点浮游植物细胞密度

Fig. 2 Cell density of phytoplankton in the different sampling sites 
$\mathrm{a}$
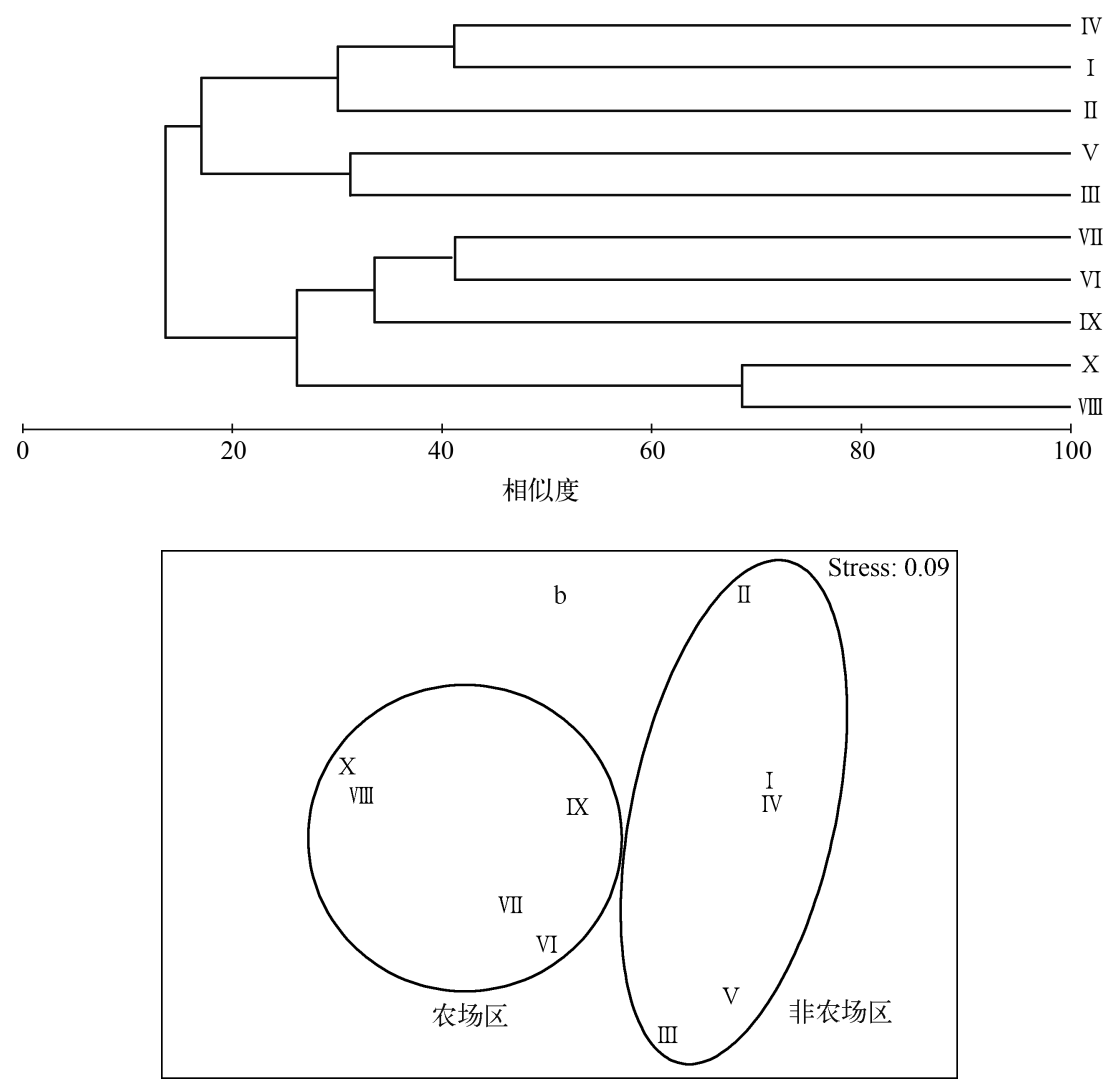

图 3 浮游植物群落组成聚类分析 ( a ) 和 MDS 排序 (b)

Fig. 3 The hierarchical cluster dendrogram(a) and $\operatorname{MDS}(\mathrm{b})$ of phytoplankton communities

农场区 5 个采样点均为溪流生境, 水体中偏弱碱性 $(\mathrm{pH}=7.05 \sim 7.60)$, 有些水体较浑浊, 平均细胞密度 为 $85.2 \times 10^{4} \mathrm{cell} \mathrm{s} / \mathrm{L}$, 所发现的浮游植物以硅藻、裸藻种类最多, 群落结构为硅藻一裸藻型. 农场区水体的绝对 优势种为适应低温和低光照的小型鞭毛藻中的啮蚀隐藻、卵形隐藻. 卵形隐藻和啮蚀隐藻大多喜好生活在 有机物丰富的水体中, 它们会随着水体有机营养物浓度增加而大量繁殖 ${ }^{[17-18]}$, 隐藻的增加是水体受污染的 直接反映 ${ }^{[19]}$. 在研究期间, 隐藻的大量检出及一些耐污指示种类的出现可能与农业生产过程中化肥的施用 并流失到水体中, 产生有机污染物有关; 另一方面, 隐藻更喜欢生活在较冷的水体中, 农场区平均水温 $\left(16.6^{\circ} \mathrm{C}\right)$ 低于非农场区. 周小愿等 ${ }^{[20]}$ 研究发现只有在水温较低的水库中出现隐藻. 农场区浮游植物的另一 个组成特点是出现了较多的裸藻门植物, 圆形囊裸藻、河生陀螺藻是 5 个小水体中的次级优势种, 这一现象 出现的原因可能与当地的农业生产及采集样点均为弱碱性小水体的生境状况有关, 裸藻大多数是非着生 性、好污性种类,适宜生长在温暖、有机质丰富的小水体中, 不适宜生长在偏酸性的水体 ${ }^{[21]}$.

非农场区采集区域所涉及的多为大型水域环境 (黑龙江、别拉洪河、大力加湖、三江湿地、别拉洪河流域 湿地), 在这些水域发现的浮游植物以绿藻、硅藻的种类和密度最多, 群落结构为绿藻-硅藻型. Round 等 ${ }^{[22]}$ 认为具有这样群落类型的水域环境常处于贫-中营养状态.

黑龙江 (样点 I ) 水域宽广, 水体较清澈, 风力扰动致使沉积物再悬浮, 给浮游植物生长提供了营养. 黑 龙江实测 $\mathrm{pH}$ 为 8.63 , 偏碱性. 一些学者认为水体 $\mathrm{pH}$ 呈偏碱性时, 浮游植物生长最好 ${ }^{[23-24]}$, 因此在 $\mathrm{pH}$ 适宜、 营养物质丰富的条件下, 在黑龙江发现的浮游植物多达 62 个分类单元, 绿藻门 45 种. 相关研究表明江河浮 游植物群落结构的普遍模式为绿藻在种类丰富度上占据优势地位, 只有少数流域是以硅藻为主要优势种 群 ${ }^{[25-27]}$. 同时在样点 I 出现了一些嗜碱性种类, 如隐头舟形藻 (Navicula cryptocephala)、弯棒杆藻 (Rhopalodia 
$g i b b a$ ). 别拉洪河 (样点 III), 属于平原沼泽性河流, 水域狭窄, 流速较慢, 这与李反修等报道的逊别拉河的浮 游植物物种组成相似 ${ }^{[28]}$, 均以硅藻为主, 且出现了 Fragilaria parasitica、F. capucina var. austriaca 喜好中一高 电解质生境的特有种类, 这可能与此段水域较浑浊, 高密度的悬浮物导致电导率、TDS 含量最高有关. 大力 加湖 (样点 II) 湖面宽广, 水体清澈, 鉴定出的浮游植物大多数为湖泊、池塘水体常见种, 典型的如浮球藻 (Planktosphaeria gelatinosa)、肾形藻 (Nephrocytium agardhianum) 和湖生卵囊藻 (Oocystis lacustis) 等. 此水域 浮游植物分布还有一个显著特点, 即实球藻 (Pandorina morum) 分布较丰富, 细胞密度也相对较高, 这可能与 船舶停靠、有机质滞留、湖中饲养鱼苗有直接关系. 不同类型的湿地, 其生境条件及浮游植物组成也有很大 差异. 本研究采集的别拉洪河流域湿地 (样点 $\mathrm{V}$ ) 以毛果荅草沼泽和漂筏沼泽湿地为主, 为缓流水湿地, 多检 出一些低流速水体常见种, 如爆裂针杆藻 (Synedra rumpens)、羽纹脆杆藻 ( Fragilaria pinnata) 等. 一般情况 下, 蓝藻更易在高温、静止水体中出现, 本研究发现断裂颤藻和颗粒颤藻等出现在水温最高 $\left(21^{\circ} \mathrm{C}\right) 、$ 、流速较 慢的别拉洪河湿地水域. 三江湿地 (样点 IV) 以塔头沼泽为主, 水体颜色较深, 泥沙多, 水流急, 属于流动水湿 地, 浮游性的硅藻、裸藻占有一定的比例, 且别拉红河湿地和三江湿地浮游植物的细胞密度均不高.

非农场区河流、湿地的浮游植物种类数均高于湖泊,谷皮菱形藻是河流生境和湿地生境的绝对优势种, 颗粒直链藻极狭变种和梅尼小环藻是湖泊生境的绝对优势种. 硅藻群落中的谷皮菱形藻、小型异极藻及梅 尼小环藻常常是有机及无机化合物污染河流中的优势种类 ${ }^{[29-30]}$, 这些浮游植物种类的出现与整个生态环境 的综合因素均有一定的相关性.

在很多水体中,水文条件对浮游植物群落结构与组成的影响相当明显 ${ }^{[31]}$. 聚类分析表明,农场区与非农 场区群落结构组成相似性系数为 13.65 , 可初步判断水文特征及生态环境不同导致了两大区域浮游植物群 落结构差异明显. 聚类分析中第一组均为非农场区采样点, 其中, 采样点 III (别拉洪河)、采样点 V (别拉洪河 流域湿地) 相似性系数为 31.38 , 采样点 III 发源于平原沼泽, 与采样点 $\mathrm{V}$ 之间水体为相互补给关系. 流动交换 的水体, 导致了两样点浮游植物群落具有的一定的相似性. 采样点 I (黑龙江) 和采样点 IV (三江湿地) 聚为 一类, 相似性系数为 41.22 , 三江湿地 (样点 IV) 位于黑龙江下游南岸, 水质含沙, 水流湍急, 水文条件更偏向 于河流的特点, 因此与黑龙江水域 (样点 I ) 的浮游植物群落结构有一定的相似性. 第二组均为农场区采样 点, 采样点 VIII 、采样点 $\mathrm{X}$ 聚为一类, 相似性系数高达 68.73 , 两样点水质浑浊, 有异味, 且绝对优势种均为啮蚀 隐藻 ( $\left.y_{\mathrm{VII}}=0.51 、 y_{\mathrm{X}}=0.56\right)$ 、卵形隐藻 $\left(y_{\mathrm{VII}}=0.31 、 y_{\mathrm{X}}=0.29\right)$. 采样点 VI、采样点 VII 聚为一类, 相似性系数 为 41.2 ,均为公路附近的溪流, 受人为活动影响较大, 两样点共同的优势种为啮蚀隐藻.

\section{2 浮游植物多样性指数分析}

群落物种多样性是衡量一定区域生物资源丰富程度的一个客观指标, 用于评价群落中种类组成的稳定 程度及其数量分布均匀程度和群落结构特征, 并常作为描述群落演替方向、速度和稳定程度的指标 ${ }^{[32]}$. Margalef $(H)$ 反映群落中物种的丰富程度, 在此次研究中, 农场区与非农场区水域 $H$ 均大于 3 , 表明两区域水域 均属于轻污染, 物种丰富度较高. Shannon-Wiener $\left(H^{\prime}\right)$ 反映群落结构的复杂程度, 其值在 2 左右浮动, 农场区 水域 $H^{\prime}$ 小于 2 , 非农场区各水域均大于 2 , 表明农场区属于 $\alpha$-中污, 非农场区属于 $\beta$-中污, 农场区浮游植物群 落结构比非农场区更复杂, 对环境变化和群落内种群变动的缓冲功能也更强. Pielou $(J)$ 用于评价生物种数 的均匀程度, $J$ 值的范围在 $0.52 \sim 0.80$ 之间, 表明农场区与非农场区水体均属于轻污染, 种间个体数较均 匀. 综合多样性指数可以看出,三江平原湿地抗远地区水域物种丰富度较高, 浮游植物多样性良好.

浮游植物作为水体环境的指示生物, 虽然不能精确地反映出水体中污染物的含量和性质, 但是可以对 生长环境的营养状态迅速做出反映, 从一定程度上说明浮游植物的生态学特点可以反映当时水体环境的特 征变化 ${ }^{[33]}$. 本文通过对三江平原湿地抚远地区浮游植物的种类、优势种群及细胞密度进行调查, 与现场测定 的水温、 $\mathrm{pH}$ 、电导率等理化指标相结合, 分析了不同水域中浮游植物的群落结构特征及其生物多样性. 总的 来看, 抚远地区水域浮游植物以绿藻门、硅藻门、裸藻门在种类及密度上占绝对优势, 农场区水体浮游植物 群落结构为硅藻一裸藻型, 农业生产过程中产生的有机污染物是此区域水体的主要污染源, 非农场区的大型 水域浮游植物群落结构为硅藻一绿藻型. 结合多样性指数, 表明三江平原湿地抚远地区水域浮游植物物种丰 富度较高, 多样性良好, 适于多种浮游植物生长.

致谢: 感谢耐美卡 (Nnaemeka Okpala) 先生对英文摘要提出的修改意见. 


\section{4 参考文献}

[ 1 ] Mitsch WJ, Gosselink JG. Wetlands: Vol. 1. Estados Unidos: John Wiley \& Sons, Inc, 2007.

[ 2 ] Suikkanen S, Laamanen M, Huttunen M. Long-term changes in summer phytoplankton communities of the open northern Baltic Sea. Estuarine, Coastal and Shelf Science, 2007,71 : 580-592.

[ 3 ] Reynolds CS. The ecology of phytoplankton. Cambridge: Cambridge University Press, 2006.

[ 4 ] Reynolds CS. Vegetation processes in the pelagic: a model for ecosystem theory. Journal of the Marine Biological Association of the United Kingdom, 1997, 77(3) : 919.

[ 5 ] 庞 科,姚锦仙, 王 吴等. 额尔古纳河流域秋季浮游植物群落结构特征. 生态学报, 2011,31(12):3391-3398.

[6] 张 华,胡鸿钧, 吕颂辉等. 浙江紧水滩水库浮游植物群落结构季节变化特征. 生态学报,2013,33(3):945-956.

[ 7 ] 詹玉涛,范正华. 釜溪河浮游植物分布及其与水质污染的相关性研究. 中国环境科学, 1991,11(1):29-33.

[ 8 ] Krammer K. Diatoms of Europe: Vol. 3. Germany:ARG Gantner Verlag KG, 2002 :584.

[ 9 ] Krammer K. Diatoms of Europe: Vol.4. Germany:ARG Gantner Verlag KG, 2003 :530.

[10］胡鸿钧,魏印心. 中国淡水藻类系统、分类及生态. 北京:科学出版社,2006:1023.

[11] 魏印心. 中国淡水藻志:第七卷. 北京:科学出版社, $2003: 200$.

[12] 王全喜,曹建国,刘 妍等.上海九段沙湿地自然保护区及其附近水域藻类图集. 北京:科学出版社,2008:69.

[13] Lampitt RS, Wishner KF, Turley CM et al. Marine snow studies in the Northeast Atlantic Ocean: distribution, composition and roles as a food source for migrating plankton. Marine Biology, 1993, 16(4):680-702.

[14] 潘继征,熊飞,李文朝等. 抚仙湖浮游植物群落结构、分布及其影响因子. 生态学报,2009,29(10):5377-5385.

[15] Rojo C. Didderential attributes of phytoplankton across the trophic gradient: a conceptual landscape with gaps. Hydrobiologia, $1998, \mathbf{3 6 9} / \mathbf{3 7 0}: 1-9$.

[16] Reynolds CS. Phytoplankton designer - or how to predict compositional response to trophic-state change. Hydrobiologia, $2000, \mathbf{4 2 4}: 123-132$.

[17] 周广杰, 况琪军, 胡征宇等. 香溪河库湾浮游藻类演替及水华发生趋势分析. 水生生物学报, 2006,30(1):42-46.

[18］王 珊,于 明. 东江干流浮游植物的物种组成及多样性分析. 资源科学, 2013,35(3):473-480.

[19] 刘建康. 东湖生态学研究 (二). 北京:科学出版社, 1995:491.

[20］周小愿,张星朗,韩亚慧等. 渭河流域典型水库浮游植物群落结构特征. 生态学杂志,2013,32(10):2772-2779.

[21 ] 施之新. 鄂西地区裸藻的初步研究. 水生生物学报, 1988,12(2):169-179.

[22] Round FE, Crawford RM, Mann DG. The diatoms: Biology \& morphology of the Genera. Cambridge: Cambridge University Press, $1990: 747$.

[23] Korneva LG. Impact of acidification on structural organization of phytoplankton community in the forest lakes of the northwestern Russia. Water Science Technology, 1996, 33:291-296.

[24] 刘春光,金相灿,孙 凌等. $\mathrm{pH}$ 值对淡水藻类生长和种类变化的影响. 农业环境科学学报,2005,24(2):294-298.

[25] Rojo C, Cobelas MA, Arauzo M. An elementary, structural analysis of river phytoplankton. Hydrobiologia, 1994, 289(1/) 2/3) :43-55.

[26] Reynolds CS, Descy JP, Padisak J. Are phytoplankton dynamics in rivers so different from those in shallow lakes. Hydrobiologia, 1994, 289(1/2/3):1-7.

[27] Istránovics V, Honti M. Phytoplankton growth in three rivers: The role of meroplankton and the benthic retention hypothesis. Limnology and Oceanography, 2011,56(4):1439-1452.

[28] 李反修, 姜作发, 李 喆等. 逊别拉河自然保护区浮游植物群落结构特征的初步研究. 水产学杂志, 2013,26(1): 32-36.

[29] Janina K, Pertti E, Barbara K et al. Use of benthic diatom communities to evaluate water quality in rivers of southern Poland. Journal of Applied Phycology, 1998,10:193-201.

[30 ] Sergi S. Diatom communities as indicators of environmental stress in the Guadiamar River, S-W. Spain, following a major mine tailings spill. Journal of Applied Phycology, 2000,12:113-124.

[31] Horn H. The relative importance of climate and nutrients in controlling phytoplankton growth in Saidenbach Reservoir. Hydrobiologia, 2003 ,504:159-166.

[32] 孟顺龙,陈家长,范利民等. 2007 年太湖五里湖浮游植物生态学特征. 湖泊科学, 2009,21(6):845-854.

[33 ] Negro AI, Hoyos CD, Vega JC. Phytoplankton structure and dynamics in Lake Sanabria and Valparaiso Reservoir ( NW Spain). Hydrobiologia, $2000, \mathbf{4 2 4}: 25-37$. 